\title{
Insecticides to combat damage by Anthonomus eugenii Cano in pepper var. Cubanelle in Puerto Rico ${ }^{1}$
}

\author{
Aristides $M$. Armstrong ${ }^{2}$
}

ABSTRACT

Two field trials were established (22 April 1985) at the Agricultural Experiment Station in Isabela to evaluate insecticides for the control of the pepper weevil, Anthonomus eugenii Cano, on pepper var. Cubanelle. The insecticides included in the first trial were permethrin $2 E$ at 0.23 and $0.47 \mathrm{~L} / \mathrm{ha}$, oxamyl $\mathrm{L}$ at 2.34 and $4.68 \mathrm{~L} / \mathrm{ha}$, and fenvalerate $2.4 \mathrm{EC}$ at 0.39 and $0.78 \mathrm{~L} / \mathrm{ha}$. In the second trial, only fenvalerate at the indicated rates was evaluated. A knapsack sprayer was used for all foliar applications. Insecticide applications were begun at fruit formation and were continued on a weekly basis. Efficacy was based on the number of fallen fruits per plot. Significant differences were obtained for fenvalerate $(0.78 \mathrm{~L} / \mathrm{ha})$ with the lowest number of fallen fruits per plot (10.07) and $90 \%$ of control and $31 \%$ losses. With oxamyl at $4.68 \mathrm{~L} / \mathrm{ha}$, control reached $79 \%$ and the second lowest number of fallen fruits per plot $(26 \%)$ with $38 \%$ losses. Permethrin was effective neither in controlling weevil damage nor in reducing losses. The best marketable fruit yield was obtained with oxamyl at $4.68 \mathrm{~L} / \mathrm{ha}$.

\section{RESUMEN}

Insecticidas para disminuir el daño de Anthonomus eugenii Cano en el pimiento var. Cubanelle en Puerto Rico.

Se realizaron dos ensayos de campo de pimiento var. Cubanelle (trasplantadas el 22 de abril de 1985) en la Estación Experimental Agrícola en Isabela para evaluar insecticidas para el control del picudo del pimiento, Anthonomus eugenii Cano. En el primer ensayo se evaluaron los insecticidas permetrina $2 \mathrm{E}$ a razón de 0.23 y $0.47 \mathrm{~L}$ ha, oxamilo $L$ a razón de 2.34 y $4.68 \mathrm{~L} /$ ha y fenvalerato $2.3 \mathrm{EC}$ a razón de 0.39 y $0.78 \mathrm{~L} / \mathrm{ha}$.

En el segundo ensayo sólo se evaluó el fenvalerato a las dosis ya señaladas. Todas las aplicaciones foliares se realizaron con una bomba de espalda; se empezaron cuando la fruta ya se estaba formando y se continuaron semanaimente. La eficacia se determinó a base del número de frutos caídos por parcela. Se obtuvieron diferencias significativas con fenvalerato $(0.78 \mathrm{~L} / \mathrm{ha})$, cuyo número de frutas caídas por parcela (10.07) fue el menor. Con $90 \%$ de control y $31 \%$ mostró el menor porcentaje de pérdidas. Con oxamilo a razón de 4.68 L/ha se logró $79 \%$ de control y el segundo número más bajo de frutos caídos por parcela $(21.0)$ con $38 \%$ de pérdidas. La permetrina no fue muy efectiva para controlar el daño causado por el picudo ni para disminuir las pérdidas. El mejor rendimiento de fruto comercial se obtuvo con oxamilo a $4.68 \mathrm{~L} / \mathrm{ha}$.

\footnotetext{
${ }^{1}$ Submitted to Editorial Board 18 October 1993.

${ }^{2}$ Assistant Entomologist, Department of Crop Protection.
} 


\section{INTRODUCTION}

The pepper weevil, Anthonomus eugenii Cano, is a pest recently introduced to Puerto Rico (1). In 1982, a 50\% loss was estimated in untreated fields of cooking peppers (1). Recently, production has diminished by 72 and $89 \%(2,4)$. The damage is caused by insect feeding and oviposition on the pepper fruit. External and internal damage on mature fruits occurs frequently (5).

Chemical control is presently the only possibility for controlling this insect. In Florida, toxaphene and kryocide have been recommended for pepper weevil control (3), but toxaphene is no longer available. Under laboratory conditions Rolston et al. (8), observed 98 to $100 \%$ mortality of adult weevils with carbaryl. In Puerto Rico carbaryl is recommended for controlling lepidoptera larvae on pepper fruits. Rolston (7) reports that some insecticides that were effective against the pepper weevil in Florida proved worthless in Louisiana. Applications of methomyl were not effective in Puerto Rico (4), whereas oxamyl and fenvalerate appeared to be promising products $(2,4)$.

We made further evaluations of these chemicals to obtain more information on the efficacy of insecticides for the control of the pepper weevil and to supply the required information to register the use of oxamyl, permethrin and fenvalerate on cooking peppers.

\section{MATERLALS AND METHODS}

Two field trials of pepper (Capsicum annum) var. Cubanelle were established (22 April 1985) at the Agricultural Experiment Station at Isabela to evaluate insecticides to control the pepper weevil. In the first trial (22 April to 1 August 1985) the following insecticides were evaluated: permethrin (Ambush $2 \mathrm{E})^{3}$ at 0.23 and $0.47 \mathrm{~L} / \mathrm{ha}(0.2$ and $0.4 \mathrm{pt} /$ A), oxamyl (Vydate $\mathrm{L}$ ) at 2.34 and $4.68 \mathrm{~L} / \mathrm{ha}$ ( 1.0 and $2.0 \mathrm{qt} / \mathrm{A}$ ), and fenvalerate (Pydrin $2.4 \mathrm{EC}$ ) at 0.39 and $0.78 \mathrm{~L} / \mathrm{ha}$ ( 0.33 and $0.67 \mathrm{pt} / \mathrm{A}) .{ }^{4}$ For the second trial (22 April to 24 July 1985) only fenvalerate, at the same rates as the first trial was evaluated. In the first trial seven applications of permethrin and oxamyl, and five of fenvalerate were made; in the second trial only five applications of fenvalerate were made. An incomplete randomized block design with three replications per treatment was used for the two tests. The experimental plot (or replicate) consisted of four 7.5-meter ( $22.5 \mathrm{ft}$ ) rows, spaced 1-meter ( $3 \mathrm{ft}$ ) apart with 0.5 -meter $(1.5 \mathrm{ft}$ ) between plants within rows. Sixty plants

\footnotetext{
3 Trade names in this publication are used only to provide specific information. Mention of a trade name does not constitute a warranty of equipment or materials by the Agriculture Experiment Station of the University of Puerto Rico, nor is this mention a statement of preference over other equipment or materials.

${ }^{4}$ Some of the insecticides are not registered for non-bell peppers or are in progress of registration.
} 
per plot were transplanted. Agronomic practices were those recommended for peppers in the area. Irrigation was applied with piston air sprayers. A knapsack sprayer was used for all the foliar applications. Applications began at fruit formation and continued on a weekly basis. Efficacy was based on the number of fallen fruits per plot (or replicate). Plots were sampled 24 to $48 \mathrm{hr}$ before and after each application. Fruits were checked for feeding scars and for oviposition punctures. Yield data were collected 7 days after the last application.

\section{RESULTS}

In the first experiment (table 1), all treatments showed fewer fallen fruits than the check, although the difference at the lower dosage of permethrin was not significant. Higher dosages showed better control. Lowest number of fallen fruits per plot (10.1) and highest control (90\%) were obtained in plots treated with fenvalerate at the rate of $0.78 \mathrm{~L} / \mathrm{ha}$. Oxamyl-treated plots at $4.68 \mathrm{~L} / \mathrm{ha}$ had $79 \%$ of control and the second lowest number of fallen fruits per plot (21.0).

No insecticide treatment was capable of eliminating the damage. Number of fallen fruits increased after each application (table 2). Low numbers of fallen fruits in the check plots in the later sampling dates indicate that the plants had no more fruits. They were the highest in terms of total number of fruits in each plant. Overall, fenvaleratetreated plots at the rate of $0.78 \mathrm{~L} / \mathrm{ha}$ exhibited better control than those with other treatments.

Application of the highest dosages of oxamyl and permethrin resulted in pepper yields significantly higher (table 1) than those of other treatments and the control. Low rates of permethrin and fenvalerate yielded no better than unsprayed (control) plots. Yields with oxamyl at the lower dosage were intermediate between best and poorest yielding treatments. Response in terms of number of fruits was similar. All insecticide treatments, except for fenvalerate at its low rates, produced significantly much more than the control. A $92 \%$ loss was obtained from the untreated plots.

For the second experiment no significant differences were obtained between treatments in terms of efficacy (table 3). Fenvalerate-treated plots at the highest dosage had the lowest number of fallen fruits (7.0) with $77 \%$ control. Data from fenvalerate-treated plots at its higher rate showed a tendency toward a low number of fallen fruits per plot at each. sampling date (table 4).

Significant differences were obtained between the fenvalerate treatments and the check in the number of commercial fruits, but not in their weight (table 3 ). A loss of $11 \%$ was obtained with the higher dosage of fenvalerate; a 70\% loss occurred in the control. 
TABLE 1.-Experiment 1: Efficacy and yield data for pepper var. Cubanelle from plots treated with insecticides to control Anthonomus eugenii Cano in Isabela, Puerto Rico, from April to August 1985

\begin{tabular}{|c|c|c|c|c|c|}
\hline \multirow[b]{3}{*}{ Treatment (ratehectare) } & & & \multicolumn{3}{|c|}{ Yield } \\
\hline & \multicolumn{2}{|c|}{ Efficacy } & \multicolumn{2}{|c|}{ Marketable fruit ${ }^{1}$} & \multirow[b]{2}{*}{$\begin{array}{l}\text { Percentage } \\
\text { fruit loss }\end{array}$} \\
\hline & $\begin{array}{l}\text { Average fallen } \\
\text { fruits per plot }\end{array}$ & $\begin{array}{c}\text { Percentage } \\
\text { damage control }{ }^{2}\end{array}$ & Number & $\begin{array}{l}\text { Weight } \\
\text { (kg) }\end{array}$ & \\
\hline Permethrin $2 \mathrm{E}(0.23 \mathrm{~L} / \mathrm{ha})$ & $62.3 \mathrm{bc}^{4}$ & 37.7 & 281 bcde & 11.7 bcde & 78.0 \\
\hline Permethrin $2 \mathrm{E}$ (0.46 L/ha) & $44.3 \mathrm{ab}$ & 55.6 & $473 \mathrm{ab}$ & $1.9 .3 \mathrm{ab}$ & 60.0 \\
\hline Oxamyl L (2.34 L/ha) & $34.5 \mathrm{ab}$ & 65.4 & $354 \mathrm{bcd}$ & $16.8 \mathrm{abcd}$ & 61.0 \\
\hline Oxamyl L (4.68 L/ha) & $21.0 \mathrm{ab}$ & 79.0 & $544 \mathrm{a}$ & $24.3 \mathrm{a}$ & 38.1 \\
\hline Fenvalerate $2.4 \mathrm{EC}(0.39 \mathrm{~L} / \mathrm{ha})$ & $47.0 \mathrm{~b}$ & 53.0 & $198 \mathrm{cde}$ & 9.2 bcde & 79.1 \\
\hline Fenvalerate $2.4 \mathrm{EC}(0.78 \mathrm{~L} / \mathrm{ha})$ & $10.1 \mathrm{a}$ & 90.0 & $360 \mathrm{bc}$ & $18.9 \mathrm{abc}$ & 31.0 \\
\hline Check & $99.9 c$ & - & $137 \mathrm{e}$ & $1.1 \mathrm{e}$ & 92.0 \\
\hline
\end{tabular}

${ }^{1}$ Number of marketable fruits per plot

${ }^{2}$ Percentage damage control $=$ [(number of fallen fruits in the check - number of fallen fruits in the treatment)/number of fallen fruits in the check $]$ $\mathrm{x} 100$.

${ }^{3}$ Percentage fruit loss $=$ [number of fallen fruits/(number of fallen fruits + number of fruits harvested) $] \times 100$.

${ }^{4}$ Values followed by the same letters do not differ significantly at $P=0.05$ with Duncan's Multiple Range Test. 
TABLE 2. - Experiment 1: Number of fallen pepper fruits var. Cubanelle caused by Anthonomus eugenij after insecticide applications ${ }^{i}$ in Isabela, Puerto Rico, from April to August 1985

\begin{tabular}{|c|c|c|c|c|c|c|c|c|c|c|c|c|c|c|}
\hline $\begin{array}{l}\text { Treatment } \\
\text { (rate/hectare) }\end{array}$ & $6-10$ & 6.17 & $6-18$ & $6-24$ & $6-27$ & $7-1$ & $7-5$ & $7-8$ & $7-11$ & $7-15$ & $7-18$ & $7-22$ & $7-25$ & $7-29$ \\
\hline $\begin{array}{l}\text { Permethrin } 2 \mathrm{E} \\
(0,234 \mathrm{~L} / \mathrm{ha})\end{array}$ & 4.0 & 33.7 & 5.0 & 38.7 & 19.7 & 78.0 & 63.7 & 110.3 & 90.7 & 110.3 & 58.0 & 176.3 & 75.0 & 132.0 \\
\hline $\begin{array}{l}\text { Permethrin } 2 \mathrm{E} \\
(0.468 \mathrm{~L} / \mathrm{ha})\end{array}$ & 5.7 & 34.0 & 3.7 & 31.7 & 12.3 & 33.0 & 16.7 & 77.7 & 61.0 & 78.0 & 31.0 & 120.3 & 37.0 & 163.3 \\
\hline $\begin{array}{l}\text { Oxamyl L } \\
\text { (2.34 L/ha) }\end{array}$ & 5.3 & 27.3 & 2.3 & 35.7 & 17.3 & 35.3 & 20.7 & 43.7 & 33.7 & 86.0 & 60.3 & 94.0 & 37.7 & 51.7 \\
\hline $\begin{array}{l}\text { Oxamyl L } \\
(4.68 \mathrm{~L} / \mathrm{ha})\end{array}$ & 2.7 & 24.0 & 0.3 & 14.7 & 1.0 & 16.7 & 10.0 & 12.7 & 6.7 & 23.0 & 3.0 & 25.3 & 5.3 & 52.7 \\
\hline $\begin{array}{l}\text { Fenvalerate } 2.4 \\
\text { EC(0.39 L/ha) }\end{array}$ & 7.7 & 32.3 & 3.7 & 46.7 & 23.3 & 70.3 & 54.3 & 153.7 & 59.7 & 122.3 & 52.7 & 43.3 & 17.0 & 57.7 \\
\hline $\begin{array}{l}\text { Fenvalerate } 2.4 \\
\text { EC(0.78 L/ha) }\end{array}$ & 1.0 & 20.7 & 2.0 & 25.7 & 3.7 & 37.0 & 24.3 & 2.7 & 0.3 & 6.3 & 3.0 & 9.3 & 3.0 & 21.3 \\
\hline Check & 6.0 & 42.0 & 9.3 & 168.0 & 82.0 & 304.7 & 44.0 & 384.3 & 71.0 & 242.7 & 72.7 & 134.3 & 27.3 & 6.0 \\
\hline
\end{tabular}

${ }^{1}$ Application dates: 10, 17, 25 June and 2, 10, 16 and 23 July. 
TABLE 3.-Experiment 2: Effectiveness of fenvalerate for the control of Anthonomus eugenii Cano and yield data from peppers var: Cubanelle in Isabela, Puerto Rico, from April to July 1985

\begin{tabular}{|c|c|c|c|c|c|}
\hline \multirow[b]{3}{*}{$\begin{array}{l}\text { Treatment } \\
\text { (rate/hectare) }\end{array}$} & & & \multicolumn{3}{|c|}{ Yield } \\
\hline & \multicolumn{2}{|c|}{ Efficacy } & \multicolumn{2}{|c|}{ Marketable fruit } & \multirow[b]{2}{*}{$\begin{array}{c}\text { Percentage fruit } \\
\text { loss }^{3}\end{array}$} \\
\hline & $\begin{array}{l}\text { Average falten } \\
\text { fruit per plot }\end{array}$ & $\begin{array}{l}\text { Percent damage } \\
\text { control }^{1}\end{array}$ & Number ${ }^{2}$ & Weight (kg) & \\
\hline $\begin{array}{l}\text { Fenvalerate } 2.4 \mathrm{EC} \\
\text { (0.39 L/ha) }\end{array}$ & $22.5 \mathrm{a}^{4}$ & 23.0 & 299 a & $10.9 \mathrm{a}$ & 31.2 \\
\hline $\begin{array}{l}\text { Fenvalerate } 2.4 \mathrm{EC} \\
(0.78 \mathrm{~L} / \mathrm{ha})\end{array}$ & $6.9 \mathrm{a}$ & 76.5 & 331 a & $12.0 \mathrm{a}$ & 11.1 \\
\hline Check & $29.3 \mathrm{a}$ & - & $77 \mathrm{~b}$ & $7.3 \mathrm{a}$ & 69.5 \\
\hline
\end{tabular}

lpercentage damage control $=[$ (number of fallen fruits in the check - number of fallen fruits in the treatment $) \div$ number of fallen fruits in the check $] \times 100$.

${ }^{2}$ Number of marketable fruits per plot.

${ }^{3}$ Percentage fruit loss $=$ [number of fallen fruits $\div$ (number of fallen fruit + number of fruits harvested) $] \times 100$.

${ }^{4}$ Values followed by the same letters do not differ significantly at $P=0.05$ with Duncan's Multiple Range Test. 
TABLE 4: Experiment 2: Number of fallen pepper fruits var. Cubanelle caused by Anthonomus eugenii following applications ${ }^{1}$ of fenvalerate in Isabela, P.R. from April 1985 to July 1985.

\begin{tabular}{ccccccccc}
\hline \multirow{2}{*}{$\begin{array}{c}\text { Treatment } \\
\text { (rate/hectare) }\end{array}$} & $6-4$ & $6-6$ & $6-19$ & $6-24$ & $7-1$ & $7-8$ & $7-15$ \\
\hline $\begin{array}{c}\text { Fenvalerate 2.4 EC } \\
\text { (0.39 L/ha) }\end{array}$ & 0 & 0 & 4.0 & 13.3 & 23.0 & 20.3 & 32.0 \\
$\begin{array}{c}\text { Fenvalerte 2.4 EC } \\
\text { (0.78 Lha }\end{array}$ & 3.3 & 0 & 1.0 & 0.8 & 17.0 & 6.3 & 42.7 \\
Check & 0.3 & 0 & 4.7 & 8.0 & 47.7 & 74.7 & 21.0 & 19.7 \\
\hline
\end{tabular}

${ }^{1}$ Application dates: June 19,25 and July $2,10,16$. 


\section{DISCUSSION}

It has been reported that permethrin, fenvalerate and oxamyl are effective in reducing weevils (6). In laboratory evaluations, permethrin $2 \mathrm{E}$ at the rate of 0.05 and $0.1 \mathrm{lb}$ a.i./A gave 70 and $88 \%$ mortality (7). Schuster and Everett (9) obtained in the field $43.5 \%$ fruits damaged by the weevil with permethrin $2 \mathrm{EC}$ and $94.4 \%$ from the check. With the $3.2 \mathrm{EC}$ formulation of permethrin, up to $66.5 \%$ of the fruit was damaged. Our findings corroborate those estimates. With permethrin 37 to $55 \%$ damaged fruits; more than $90 \%$ from the control plots.

With oxamyl 2L, Schuster and Everett (9) reported $62.8 \%$ fruits damaged by the weevil. In Puerto Rico, Gordon (4), using oxamyl L at its higher rate, reported good control of the weevil with only 15 to $44 \%$ loss. With the same rate of oxamyl Gordon (4) used Acosta et al. (2) obtained a significantly lower percentage of fruits damaged by the weevil than with other treatments. Our data with oxamyl corroborate this result. At its higher rate, we obtained $79 \%$ damage control with $38 \%$ loss in production against $92 \%$ loss in the check.

Fenvalerate $2.4 \mathrm{EC}$ has previously been reported to give average to above average control $(4,9)$. In our results, the best control and the lowest losses occurred with $4.68 \mathrm{~L} /$ ha fenvalerate.

Our results corroborate previous work that shows these insecticides reduce, but do not eliminate, the weevils. To minimize their economic impact on yield, it is imperative to apply insecticides to obtain good marketable yield. Fruit losses above $90 \%$ can be expected from untreated fields. For weevil control and low loss percentage the insecticides oxamyl and fenvalerate at their higher rates are promising candidates toreduce croplosses from the pepperweevilinPuerto Rico.

\section{LITERATURE CITED}

1. Abreu, E. and C. Cruz, 1985. Occurrence of pepper weevil, Anthonomus eugenii (Coleoptera:Curculionidae). J. Agric. Uniu. P.R., 69(2): 223-24.

2. Acosta, N., N, Vicente, E. Abreu and S. Medina-Gaud, 1987. Chemical control of Meloidogyne incognita, Rolylenchulus reniformis and Anthonomus eugenii in Capsicum annum and C. frutescens. Nematropica 17(2): 163-69.

3. Burke, H. R. and R. E. Woodruff, 1980. The pepper weevil (Anthonomus eugenii Cano) in Florida (Coleoptera:Curculionidae). Fla. Dept. Agric. and Consumer Serv., Div. Plant Ind., Entomol. Circ. 219.

4. Gordon-Mendoza, R., 1984. Control químico y biología del picudo del pimiento, Anthonomus eugenii Cano (Coleoptera:Curculionidae) en Puerto Rico. M.S. Thesis, University of Puerto Rico at Mayagüez.

5. Gordon, R. and A. M. Armstrong, 1990. Biología del picudo del pimiento, Anthonomus eugenii Cano (Coleoptera:Curculionidae) en Puerto Rico. J. Agric. Univ. P.R, $74(1): 69-73$.

6. Ozaki, H. Y. and W. G. Genung, 1982. Insecticide evaluation for pepper weevil control. Proc. Fla. State Hort. Soc. 95: 347-48. 
7. Rolston, L. H., 1977. Insecticide tests in laboratory and field against the pepper weevil, Anthonomus eugenii Cano. J. Georgia Entomol. Soc. 12(2): 117-20.

8. Rolston, L. H., J. Bagent and J. Abadie, 1977. The pepper weevil. Louisiana Agric. 20(4): 14-15.

9. Schuster, D. J. and P. H. Everett, 1982. Control of the beet armyworm and pepper weevil on pepper. Proc. Fla. State Hort. Soc. 95: 349-51. 